\title{
Introduction: Worth the Wait
}

\author{
Andreas Bandak and Manpreet K. Janeja
}

Waiting is a ubiquitous and familiar phenomenon. It could even be said that waiting is an integral part of human life. Nevertheless, the phenomenon of waiting is just beginning to be taken up as a theme of ethnographic enquiry in its own right in recent social and cultural anthropological work. It is noteworthy that we have had to wait all these years for an active, focused engagement with such a pervasive phenomenon. In this edited volume, we aim to explore various modalities of waiting. Our central claim is that waiting must be conceptualized both as figure in its own right as well as a trigger for various forms of social energies. Waiting, we therefore propose, must be scrutinized in relation to the central figures of hope, doubt and uncertainty. Waiting is a particular engagement in, and with, time. For a period, short or extended, an individual or a collective finds itself placed in a situation where what is hoped for or anxiously anticipated has not yet been actualized. This period allows an exploration of what Hannah Arendt designated as 'the human condition' (1998 [1958]). Arendt wrote of 'man's' relation to time in Between Past and Future (1993 [1968]: 11):

Seen from the viewpoint of man, who always lives in the interval between past and future, time is not a continuum, a flow of uninterrupted succession; it is broken in the middle, at the point where 'he' stands; and 'his' standpoint is not the present as we usually understand it but rather a gap in time which 'his' constant fighting, 'his' making a stand against past and future, keeps in existence. Only because man is inserted into time and only to the extent that he stands his ground does the flow of indifferent time break up into tenses.

We are grateful to James Bielo, Marilyn Strathern, Martin Demant Frederiksen, Michael Herzfeld and Simon Coleman for their incisive comments and suggestions. All infelicities remain our own. 
While we would be reluctant to write of 'man' in the same way as Arendt does in this passage, she captures something important, namely that modernity places human beings in a particular relation to time. In a modern conception of time, human beings are situated in a gap, in an interval where there is an engagement with different forces. Arendt concedes that this conception is not a solely modern phenomenon, rather the gap may coexist with human beings as such (1993 [1968]: 13). For Arendt, the gap in which human beings find themselves is not related to the figure of waiting. The gap, in her understanding, is where thought and action can take place in a 'constant fighting. Given that Arendt's is a particular modernist conception of time, and of life as being lived in an 'interval between past and future, more ground needs to be covered in order to understand the 'human condition' in all its diversity as well as potentials that variously conceived temporalities and temporal gaps and intervals might afford for social and cultural life. In these variegated temporal engagements, it is important to explore how and when this is experienced as a passive waiting or when this is an active waiting for something (Marcel 1967; Crapanzano 1985; Hage 2009). In other words, waiting as a concept enables us to explore ethnographically what forms action, thought and social relationships acquire in diverse engagements in, and with, time. Conversely, we need to explore what forms of thinking, acting and relating are shunned, occluded or neglected when situated in these temporal configurations. What happens, we ask, when such temporal relations, gaps and intervals shift from being temporary phenomena to more permanent and pervasive figures, when - to paraphrase Veena Das (2016) - they may even become a form of life? What happens to the experience of time and the capacity to wait in variegated configurations of power, new technological inventions and legal regulations? And to follow up on Arendt's argument above, how do gendered roles and cultural ideals form repositories to persist, endure and deal with waiting, or we might ask, how is waiting itself regularized by particular cultural norms? How can we use the ethnographic method and the various forms of waiting it entails in exploring the phenomenon of waiting? How do we, as anthropologists, work, plan and also wait in the crafting of our analyses? How are we to assess when something is worth the wait, and how do we act and think while we are at it?

The phenomenon of waiting needs further unpacking, as the French philosopher Gabriel Marcel points out in his seminal text 'Desire and Hope' (1967). Inspired by Christian theology, Marcel distinguishes between desire, on the one hand, which is intrinsically insatiable, impatient and does not tolerate any form of delay (1967: 280), and hope, on the other, which involves waiting. In waiting, 'we will have to recognize the existence of a range which goes from inert 
waiting to active waiting' (1967: 280). In instances of inert or passive waiting, there is a general feature of confidence in the outcome or, at times, perhaps an indifference to it. Hence, one is capable of biding time, and awaiting the anticipated outcome more or less patiently, without necessarily being particularly anxious about the outcome. However, in the moment this certitude is lost, an interior debate' arises. Such an internal tension is, according to Marcel, emblematic of active waiting. And when such an internal debate dies out we may see despair taking over, despair as the closed and inevitable outcome of a situation. Active waiting, on the other hand, keeps open what is anticipated, and therefore entails hope understood as generative of action (1967: 282). Such a conceptualization of the intricate interplay between different forms of waiting, or a range of waiting as Marcel puts it, is significant, and calls for further exploration. It is in this interplay that we find a way in the interstices of collective and individual forms of waiting, a way in between modalities of waiting that opens up for what could be called the politics and poetics of waiting (cf. Clifford and Marcus 1986).

We shall return to these dimensions of waiting in due course, but here we suggest some preliminary directions. By the politics of waiting, we refer to engagements with the structural and institutional conditions that compel people to wait. Waiting has been, and is increasingly used as, an instrument to elicit particular forms of subjectivities, or as a weapon to make existence intolerable for certain groups such as refugees and asylum seekers trying to obtain the right papers (Gaibazzi 2012; Andersson 2014a: 796). While this dimension of waiting is an important avenue for research, we argue that it must be complemented with a focus on the poetics of waiting. By the poetics of waiting, we refer to the existential affordances of being placed in temporal relations, gaps and intervals where the outcome is uncertain. Following Herzfeld's use of social poetics, we do not see this move as a matter of aestheticizing social life but rather one of situating semiotic qualities, the active use and reading of signs, social performances as well ambiguities and undecidedness in the midst of human endeavours crossing individual and collective forms of action (2005: 23ff., 2016; see also 1985: 10). It is important to bring these dimensions into the conversation on waiting as we are thereby allowed to scrutinize how people in ostensibly similar conditions still experience and deal with them differently. Waiting may both forge innovation and creativity as well as destroy the persons waiting. It is this uncertain interplay that this volume sets out to explore. The central ethnographic and anthropological impetus for this edited volume is not to side with either a structural and institutional perspective or an existential one but rather to foster a conversation between them. 


\section{Politics and poetics of waiting}

The very familiarity of waiting (Schweizer 2005: 778) has perhaps contributed to the relative neglect of the study of the phenomenon of waiting in a concerted manner. The anthropological and, more generally, social science literature that has focused explicitly on 'waiting as a social fact' (Eriksen 2016: 78; see also Schweizer 2008: 1) by and large remains sprawling and dispersed, in contrast to the scholarly attention devoted to time and temporality, with there being repeated calls (e.g. Conlon 2011) for the need to develop an 'ethnography of waiting' (Sutton et al. 2011). So far, only a limited but growing number of anthropological and ethnographic works have dealt with waiting as an analytical category in its own right. Significant works include Craig Jeffrey's anthropological study Timepass: Youth, Class, and the Politics of Waiting in India (2010a), Javier Auyero's sociological account Patients of the State: The Politics of Waiting in Argentina (2012), and Ghassan Hage's interdisciplinary edited volume Waiting (2009). ${ }^{1}$ The dominant position in this recent work has focused on 'the politics of waiting' (Jeffrey 2010a; Auyero 2012). Auyero's ethnographic analysis of the extended waiting of poor people seeking state social and administrative services in Buenos Aires is inspired by a mainly Bourdieuian approach, where waiting is analysed predominantly as a technology of governance: power is effectuated through its exercise over other people's time (Bourdieu 2000: 228) and in how they are made to wait, thereby generating particular forms of subjectivities. ${ }^{2}$ Jeffrey's incisive ethnography of 'chronic waiting' amongst unemployed lower middle-class young men in the Indian city of Meerut analyses waiting as a social experience as well as a basis for political mobilization and democratic politics. His work (2010a: 19-23, 2010b: 468) broadly combines a critically minded Bourdieuian approach with Paul Willis' $(1977,2003)$ work on the everyday social practices of young working-class men in a British school engaged in 'partial penetrations' of dominant structures, thereby highlighting the mutual interplay of creative agency and broader social structures. Although it is perilous to draw neatly bounded conclusions, we could broadly say that the perspective in these works has resonances with earlier works focusing on the destitute and disadvantaged, whether from lower classes, youth, refugees or otherwise marginalized positions (e.g. Stepputat 1992; Chakrabarty 2000; Appadurai 2002; Corbridge 2004; Bayart 2007; Conlon 2007). While this analytical stance is much needed in order for us to better conceive of the ways in which the contemporary world functions, this encapsulates us in a particular way of thinking about waiting. Waiting is often used politically but it also entails facets that go beyond the domain of 
politics, political mobilization and everyday micro-politics (also see for example Johnson-Hanks 2005; Mains 2007).

Waiting is arguably as old as life itself, and its genealogy, therefore, is not to be taken as congruent with politics and governance alone. Our critical addition to the existing literature here is to untie politics, governance and waiting, to enable us to explore what a poetics of waiting might look like. This being so, the objective is not to counterpose poetics to politics. Rather, inspired by James Clifford and George Marcus' seminal work on the 'inseparability' of the 'poetic and the political' in 'writing culture' (Clifford and Marcus 1986; Clifford 1986: 2), the purpose is to situate the analytical potential of the concept of waiting in a more nuanced manner by attending to the mutual interplay of these dimensions. While Hage's (2009) edited volume prefigures this, exploring waiting from a range of disciplinary perspectives, in this volume we endeavour to accomplish a more vigorous anthropological engagement by incorporating a wider range of focused and comparative ethnographic studies of waiting that allows us to see both the political usages of waiting as well as the ways in which waiting may open up for the otherwise (Povinelli 2011, 2012), thereby eliciting important critical questions. We seek to engage with a plurality of ways of being and inhabiting time as seen through the figure of waiting. In order to accomplish such a move, we work with waiting as a category that allows people's doubts and uncertainties (Engelke 2005; Pelkmans 2013) to coexist with potentials of hope (Crapanzano 2003; Hage 2003; Miyazaki 2004; Lindquist 2006; Zigon, this volume). Waiting often entails oscillations between these variegated stances; it is a form of becoming emergent in the very oscillations between doubting and hoping but also of suspending both. In the process of focusing on waiting as a conceptual lens to examine the variegated human condition, this volume also highlights waiting as a central methodological tool integral to the anthropological enterprise. It explores the politics and poetics of waiting as uncertain interplays between hoping and doubting. In so doing, it enables us to critically approach the precariousness of existence, made more urgent by current conjunctures of simultaneous waiting and speeding up across scales, a theme we return to later.

The precarious conditions of vast swathes of the world's human inhabitants offer no shortage of structurally and institutionally imposed forms of waiting. ${ }^{3}$ The destinies of large numbers of displaced people - migrants, refugees and asylum seekers - to a great extent bespeak the travails and impasses experienced in parts of the world where entire nations seem to be waiting for better times (Bayart 2007). At the time of writing, the continuing crisis in Syria offers ample evidence of how people wait for rescue in cities such as Homs and Aleppo. Or how 
Syrian refugees, now in camps in neighbouring countries such as Lebanon, Jordan and Turkey, await opportunities to cross the Mediterranean Sea or by other means attempt reaching Europe and other destinations or, in what for many is now a longer term perspective, to return to Syria in better and safer times. However, the Syrian crisis and the concomitant refugee situation also shows how European regulations and legislations affect the incentives of people to stay or to attempt to ride their luck en route to what are perceived as better and safer locations (cf. Schuster 2011). In general, we find that attending to the flourishing literature on migration offers abundant proof of tensions between different forms of waiting. Waiting may here be seen as an imposed form of sanctioning used to slow down movement towards Europe, for instance, a means to ward off people and keep them out by making them linger and await decisions beyond their control (Lucht 2012; Andersson 2014b). Such prolonged forms of waiting have a corrosive effect on many undocumented migrants, making their entire situation one of transience, and simultaneously a situation of scrutiny and objectification in the form of external assessments of value or experiences of personal threats in one's place of origin. Bredeloup describes the impact of forms of transit landscapes on migrants as follows (2012: 465):

Daily life passes slowly and although the waiting time is fully occupied by activities necessitated by daily survival, [it] can easily seem endless, punctuated only by occasional events which may break the ongoing routine and lead them to rearrange their route. [...] The act of waiting in transit paradoxically expands time, but compresses space for immobile individuals.

However, waiting does not merely affect people on the move but also the whole chain of relations and networks, where those not on the move themselves are also incorporated into a wider form of waiting, be that in the form of waiting for news on the successful entry of the former into the desired destination after a dangerous and clandestine travel or for oneself to embark on migration towards a desired destination (Vigh 2009; Reeves 2011; Graw and Schielke 2012; Griffiths 2013; Elliot 2016). Furthermore, once inside Europe, migrants and asylum seekers are exposed to new forms of vulnerability, where asylum is becoming increasingly tied to the needs of the labour market and, to a lesser extent, to an assessment of actual threat in the place of origin (Fassin 2013). Thus, the process of seeking asylum increasingly draws out over months, and even years, of waiting in camps and asylum centres inside as well as outside Europe (Whyte 2011; Rotter 2016).

In an ethnographic study of camps outside Europe, Agier (2002) characterizes the camps of Dadaab in northeast Kenya - with refugees from Somalia, Southern Sudan, Ethiopia, Eritrea and Uganda - as a novel socio-spatial form: 'city-camps'. 
Such city-camps are created by the coupling of war with 'humanitarian' intervention in a situation of emergency, but generally last far beyond the duration of the emergency, though politically not recognized as an enduring reality. Consequently, the housing of displaced persons and refugees in these camps creates a new category of world population and a new component of the human condition, placed in 'waiting zones' outside of society. The camp as a waiting zone outside of society (as well as the 'self-settled' sites of displaced persons and refugees on the city outskirts) is 'liminal' (cf. Turner 1969) in the sense that it remains in peripheral zones 'provisionally or illegally occupied', with '[n]othing [...] ever [...] [being] brought to completion in these contexts' (Agier 2002: 337; also see Agamben 1998; Turner 2012), which contrasts with the variegated speeds, mobilities and temporalities in society beyond the camp.

Studies of urban slum dwellers in large parts of the world offer another window into the precariousness and uncertainty generated by structurally imposed forms of spatial and temporal waiting, especially in the 'Global South', where neoliberal economic reforms have led to vast 'floating populations' (Bayart 2007) forced to wait for food, education, health care or shelter (Appadurai 2002; Jeffrey 2008: 954; Janeja 2014). Housing crises in cities of disposal such as Mumbai show that the 'tyranny of emergency' (Bindé 2000) prevents them from effectively building long-term assets (Appadurai 2002: 30), and compels them to live as if in a constant and immediate present, a forever 'temporary' condition. ${ }^{4}$ This tyranny of emergency might entail 'some degree of waiting (which is usually lived as "impatience")' but it has a temporal structure that obstructs any kind of long-term perspective, accompanied by the prospect or promise of a subsequent stage that would effectively facilitate the development of alternatives to the situation (Procupez 2015: S56), and thus excludes the possibility of a 'plan' (cf. Abram and Weszkalnys 2011). ${ }^{5}$ Furthermore, as Procupez shows in her historically informed ethnographic study of poor urban families in Buenos Aires residing 'temporarily' in government-subsidized 'welfare hotels', the recipients of housing subsidies have to meet specific strict criteria delineated by state regulation, in turn redefined by different administrations at different points in time, and substantiate it with documents in order to qualify as 'needy' and requiring assistance in a 'housing emergency'. Auyero's ethnographic study, referred to earlier, also depicts how and why welfare clients in Buenos Aires become disempowered 'patients of the state, with their compliance emerging as the outcome of incorporating domination in what he describes as the politics of waiting (Auyero 2012: 155; but see also Mathur 2014). 
However, drawing on Hage (2009), Procupez points out that what is overlooked in this portrayal of the politics of waiting is the fact that modalities of waiting are shaped not only by those who make others wait, but also by those who wait. She thus shows how the aforementioned recipients of housing subsidies organized themselves into community-based housing grassroots organizations, which subsequently developed more encompassing demands, e.g. access to public funding for collective housing projects to be directly administered by the participants themselves, which would enable them to find affordable ways of becoming legal residents while actively contributing to the construction projects with their own labour. This process of collective organizing requires patience as a necessary disposition, not only for negotiating bureaucratic delays and peer disagreements, but also for coping with the prospect of future change. Patience here is a political stance that involves a shift in perspective from the immediate to the longterm. It is better understood as an active engagement with, or a 'new experience of inhabiting time [which] combines both urgency and restraint', a collective mode of being or disposition toward 'the experience of temporality within a project-based politics. Thus, for Procupez, patience here is 'waiting while working to make something happen, it is [reluctant] hope and the formation of a collective subjectivity' (2015: S56-S64).

The capacity of people to transform their needs into a collective claim, and to patiently work to organize themselves into a long-term project that endeavours to confront and solve this claim, constitutes and becomes, for Appadurai (2002: 28-30; 2013a: 126-127), a 'politics of patience'. Delineating this as fundamental to democratic citizenship and participation ('deep democracy'), he describes the politics of patience as a slow collaborative process that entails practices of accommodation, negotiation, long-term asset building and cumulative change rather than a politics of confrontation. When the unhoused or underhoused millions in Mumbai - or Calcutta or Durban - mobilize to demand better housing, they know they must prepare to wait for unascertained periods of years or even decades, in the face of uncertainty created by real estate development as well as state-sponsored demolition. Hoping for change in this context rests on negotiating emergency and urgency with patience, which requires the 'capacity to aspire', defined as a capacity that is 'a navigational one [...] that allows people to make their way from more proximate needs to more distant aspirational worlds' (Appadurai 2013a: 213). But this cultural capacity to aspire or hope for possible futures, Appadurai points out, is unequally distributed among wealthier and poorer communities (also see Hage 2003, 2016: 466-467), calling for scaled exercises in building and nurturing this capacity as a collective asset amongst 
the latter. This is illustrated by the daily organizational work and public rituals of the SPARC Alliance, a coalition of an NGO and two slum-based groups that has led a wide range of neighbourhood development interventions in Mumbai's slums by working on non-confrontational collaborations with local state and international development agencies. 'Politically organised hope thus produces in bare citizens the internal resources to see themselves as active participants in the arduous process of waiting; it converts the passive "waiting for" into the active "waiting to": waiting to make the next move in the queue and ultimately to claim the full rights of citizenship' (Appadurai 2013b: 13).

Like collective patience, individual endurance gets intertwined with hope (and despair), and might elicit pity and compassion as well. Kwon (2015) describes how, for Korean Chinese migrants moving to South Korea and their families who wait behind, waiting has emerged as an essential activity, a form of unpaid affective work that requires the capacity to endure loneliness to maintain a stable love life and the flow of remittances in the midst of hope, anxiety and uncertainty. A figure such as Penelope may also be worth pondering over here. Penelope awaits Ulysses' return, weaving by day and unravelling the weave by night, and hence indexes not merely a passive form of surrender to circumstances but an active form of endurance amidst the most mundane of chores. In her efforts Penelope cannot be reduced merely to a subject that evokes pity. Rather, she keeps her hope alive in her patient resilience. The figure of Penelope therefore bespeaks how we cannot situate waiting merely in a frame of suffering but rather must attend to the variegated responses to lived historical circumstances and concrete situations. Therefore, we see a pertinent call in Joel Robbins' analytical move to go beyond the suffering subject (Robbins 2013). Where despair, ruin and pain all are prevalent figures in the contemporary world, an anthropological engagement ought to explore such situations as diverse forms of interacting with the world. In Arendt's conception, we need to be cautious with accounts that rest solely on pity (1990 [1963]: 70, 85-88). Pity may heighten the awareness of the predicament of the other, but while doing so it presents the other as remote. Passion, and compassion, by contrast engage with the other and minimize distance. In attending to the poignant making, unmaking and remaking of lifeworlds, an anthropologically ethnographic engagement needs to address more than pity, so that we can learn something through the different ways the world is being negotiated, lived, endured and acted upon (see also Boltanski 1999; Sennett 2003: 142ff.; Jackson 2005: 154; Gullestad 2007: 22). It is therefore pertinent that we attend to the temporalities at play in the phenomenon of waiting, and in the discipline of anthropology. 


\section{Waiting with or without an end - temporalities and waiting}

In the anthropological record, temporality has been a central theme, ranging from Evans-Pritchard's study of Nuer time-reckoning (1939), and studies of waiting as deferral between exchanges as critical to a gift (Mauss 2000 [1925]; Gregory 1982) to the interrogation of the time of self and other (Fabian 1983; Dalsgaard and Nielsen 2013) and the renewed interest in recent discussions on rupture and continuity (Robbins 2007; but see also Meyer 1998; Engelke 2010). A key theme in one recent formulation has been Joel Robbins' argument that anthropology as a discipline has predominantly been a discipline of continuity (2007). By examining Christian categories of time as central to the formation of modern conceptions of time, Robbins argues that Christianity breaks with the past and affords rupture as a central model for social change. One of the central places where such a model is found is in conversions. In converting, individuals come to see their past in a new light, and more or less actively dissociates it from past practices and convictions. Conversion, however, is not merely a matter of acting upon the past but also of coming to anticipate a particular present and future. Robbins presents this as follows (2007: 12):

Much of the imagery of a rupture in life's normal time line that is present in many models of conversion is also given elaborate and explicit treatment in discourses on the coming of the millennium. The watchful waiting for a messiah who will come like a thief in the night that many Christians enjoin on one another is premised on the idea that at any moment a future could arrive totally independent of the causal thrust of the present.

For Robbins' interlocutors in Papua New Guinea, this means that the entire Urapmin community, after a collective conversion to Christianity, lives in a state of expectation, waiting watchfully and vigilantly for the second coming of the Messiah, ready to seize or be seized by radical change (2004: 303). For the Urapmin, millennial expectation oscillates between everyday concern and talk about Christ's second coming, and then at times engages with more marked and heightened ritual practice to prepare themselves individually and collectively for this event (see also Robbins 2001: 527ff.). Other recent ethnographies have shown how followers of various strands of Christianity are situated in relation to the future or, vis-à-vis engagement with - or perhaps rather disengagement from - politics. Hence, Jane Guyer argues that a loss of near future can be found with Christians living in light of Christ's second coming (2007), and Jon Bialecki delineates how the capacity to act and deal with politics risks becoming 
meaningless if what to strive for is placed outside or beyond this world, and rather in the world to come (2009).

Although Robbins' cogent reflections on Christian models of time in relation to rupture, discontinuity, and the event are not uncontested (see, for example, Hann and Goltz 2010; Lazar 2014; Tomlinson 2014), it is possible to extend this line of inquiry further, since studies of Christianity offer an interesting avenue for exploring different modalities of waiting and various configurations of relations towards the end of time. Robbins himself draws upon Walter Benjamin's famous text 'Theses on the History of Philosophy' where the latter argues against the idea of progress as such (1999b: 252; see also Robbins 2010, 2011). The experience of the past is always carried onward at the brink of destruction and in moments of danger, and hence, it is important to dismantle the ideology of progress as if humanity exists in empty homogeneous time. To Benjamin - as well as Robbins it is important to be open for messianic moments in time. For Robbins, the important point is that change may not always come as a discrete and continuous process as something merely happening in time but rather when something happens to time itself (2007: 9). For Benjamin, this is part of a meditation on how empty homogeneous time is always filled by the time of the now, jetztZeit, and the irruption of the unexpected also, perhaps especially in moments of danger and destruction (XIV). Time in this sense is constantly open to the return of the Messiah. But in Benjamin such a return causes trembling as well as hope because catastrophe and liberation here are tied together (cf. Taussig 2006).

The figure of the second coming of Christ, parousia, an important theme in Christian thought more widely, connotes hope, but also the end of the world as we know it. Reinhart Koselleck may be instructive here in his original engagement with the semantics of modern time in his Futures Past (2004, German original 1979). In this work, he reflects on the categories of time, and most significantly, on the relation between spaces of experience and horizons of expectation in the formation of historical time. Koselleck is preoccupied with western conceptions of time, where Christianity is a central figure to reckon with. In Christian history, time was eschatological. Time had a beginning and an end. Christ had, by his coming, inserted a particular orientation in time as an already, not yet. Koselleck formulates this insight eloquently (2004: 11): 'Until well into the sixteenth century, the history of Christianity is a history of expectations, or more exactly, the constant anticipation of the End of the World on the one hand and the continual deferment of the End on the other' In this formulation, what we see is that Christianity gave rise to a particular historical conception of time as linear, but it also inserted a particular set of expectations 
toward the time to come and the end of this world. As the first Christians awaited the second coming as imminent, attested quite clearly by the letters of Paul, they saw their life in a particular light, e.g. did it make sense to marry or to collect earthly belongings if Christ was to return in the next moment? Thus, in this sense some things were less relevant, than others, to carry out, if Christ was to return imminently. However, with the passage of time, the Church came to be suspended between Christ's first and second coming, and thereby regularized the expectations of the time to come (Koselleck 2004: 13; see also Reinhardt, this volume). The Church had to obtain a delicate balance between the hope of parousia and the threat of the end.

A further extension of the legacy of Pauline thinking is to be found in Giorgio Agamben's exploration, in The Time that Remains (2005 [2000]). ${ }^{6}$ Agamben describes Paul as an apostle, and not a prophet, because of his relationship to time. The prophet speaks from the perspective of the people waiting for the coming of the Messiah, reading the signs of his coming in the events experienced. The apostle, by contrast, speaks from a different position, namely that of the arrival of the Messiah. The time of the prophet is that of the future, while the time of the apostle is that of the present. And for Agamben the time that interests the apostle is not the end of time but rather the ending of time; the time that remains between time and its end (2005 [2000]: 62). Therefore, for Agamben neither the instant nor the continuum are apt metaphors for messianic time (see also Agamben 2007 [1978]). Messianic time is rather to be understood as the interstice or gap opened by the already not yet, that salvation has already arrived but is yet to be fulfilled. In Agamben's conception, this amounts to an additional or transitional time. That is to say, secular time, or chronos, is interlaced with something else, namely kairos, decisive moments with the potentiality of the irruption of the unexpected. To live life as 'already, not yet' implies that waiting becomes a critical component of existence as characterized by a charged attitude, in that one is living a life in anticipation.

But such anticipation may not be directed or specified vis-à-vis defined ends. Perhaps it is precisely this lack of specification that allows waiting to become a critical resource unbound from pre-existing coordinates (see also Frederiksen, this volume). Such a form of perseverance is proposed in the critical work of Jacques Derrida and his meditations on the figure of messianism. In his Specters of Marx, he engages with the 'messianic', as he prefers to call it (2004 [1993]: 210), as a form of 'waiting without a horizon of expectation' (2004 [1993]: 211). Derrida in this sense talks of the messianic without messianism, an open waiting for the future without fixed coordinates. In this understanding, the messianic 
would stop being messianic, if it was no longer a form of hesitation in the face of the time to come. Thus, the messianic here becomes a cipher for an irresolvable waiting that keeps open the possibility of meeting the future. Waiting here is devoid of a specified end.

\section{Temporalities, modernities and crises}

As anthropologists, we are well aware that much of our discipline has had a particular history of resting on Christian or western framings of many of our concepts. Mindful of Talal Asad's injunction, we are not aiming for an uncritical use of such concepts and understandings as indexical of some kind of universal history (1993). Rather, the genealogical work involved in setting straight the formation of many of the concepts of our discipline, and unbinding them from their Western historical underpinnings and Christian legacies, invites us to revisit the onset of modernity in Europe and North America, with a view to engaging with how these particular historical trajectories of modernity have impacted on understandings and experiences of time and temporalities in the 'West' as well as the 'Global South', the latter understood as postcolonial Africa, Asia, Meso and South America, and frequently perceived as occupying the 'waiting room of history' (Chakrabarty 2000: 256), although parts of it are now 'emerging.

We begin by returning to Koselleck's work. Koselleck delineates how western modernity creates novel spaces of experiences and horizons of expectations that depart from Christian eschatology. For him, modernity is characterized by a secularization of time (2004: 265). Time and ideas of the end are untied from a religious horizon, and the collective figuring of the future becomes that of a politics of man's making instead. To Koselleck, this is a new and different plane of historical time. Modernity, for him, is characterized by an acceleration or speeding up $(2004: 3,11,50)$. But also by a secularization of time in that prophecy becomes obsolete, and finds its contrasting replacement in prognosis and rational planning of time $(2004: 19,265)$. Central components in this portrayal of western history are events such as the Reformation, the Thirty Year War and the French Revolution, which in various ways made human activity - and not divine providence - the scale to reckon with. With these significant events in western history, the future became open to human planning and intervention (see also Arendt 1990 [1963]: 55; Arendt 1993 [1968]: 65). Associated with this modernity came ideas of progress and process as dominant idioms for grasping people's experiences of time as well as conceptualizations of history. 
Where such seamless accounts of modernity have long been questioned anthropologically and ethnographically for their ethnocentric and allochronistic bias (e.g. Wolf 1982; Fabian 1983: 32ff.; Miller 1994; Arce and Long 2000; Englund and Leach 2000), it still seems that pertinent themes need further unravelling. On the one hand, modernity needs to be pluralized as people have never just lived the same form of modernity, but rather multiple modernities. On the other hand, as argued by Michel Serres (Serres and Latour 1995 [1990]: 61), and later furthered by Bruno Latour ([1993]), humans have 'never been modern'. Or perhaps, the distribution between what is perceived as modern time and what is not attests to the different temporal planes in which human activity is inscribed. One intervention that points us in this direction is found in Laura Bear's recent engagement with what she designates the anthropology of modern time (2014). Bear argues that modern time has not yet been understood and explored anthropologically. One of her central contentions is thus that we need to explore how modern time persists as a central epistemological underpinning to local conceptions of time, also when various rhythms and social times are placed hierarchically in relation to it. In other words, modern time organizes different social times. In this sense, even though modernity is not as seamless as the accounts Arendt and Koselleck would suggest, it still organizes horizons of expectation and spaces of experience. Bear, without dealing with Arendt and Koselleck, seems to point in the same direction in that she argues that modern time, instead of being a harbinger of progress, is also rife with doubt. In her formulation (Bear 2014: 6): 'Modern time is characterized by unprecedented doubt about, and conflict in, representations of time.' We will return to the configurations of doubt again shortly but here consider the characteristics of the organization of modern time further.

The characteristics of modern time centrally revolve around particular orderings of time. Hence, the clock and the calendar have been instrumental in organizing the lives of individuals and collectives in their function as social forms of discipline, regimented routines, and technologies of the imagination (see Benjamin 1999; Foucault 1991 [1975]; Benjamin 1999; Weber 2013 [1922]). Modernity thereby advanced a particular organization of time and planning where abstract time materialized people's practices and experiences. Agamben formulates this as follows (1993 [1978]: 105): 'The modern concept of time is a secularization of rectilinear, irreversible Christian time, albeit sundered from any notion of end and emptied of any other meaning but that of structured process in terms of before and after.' Modern factories and modern cities can be seen as emblematic markers of such forms of time. Here the notion of modern time has 
often been paired with industrial time, where efficiency, work and productivity laid claims to the time of labourers, and also produced novel spaces of both leisure and dead time (see also Thompson 1967; Giddens 1991). The history of modern time is, therefore, also the history of social organization, where abstract time and regulation by the state are institutionalized. The modern focus on progress and efficiency also produces its antinomies, namely what falls out or needs to be controlled, be it in the form of bureaucracy and paper work (Blom Hansen 2005; Navaro-Yashin 2007), legal regulation (de Genova 2002) or novel technological forms of control and auditing (Power 1997; Strathern 2000). Modernity did not obliterate different experiences of time but it organized social time in relation to more regularized schemes of production. Moreover, as Jeffrey (2008: 955) points out, the institutionalization of chronological time associated with the onset of modernity in Europe and North America in the nineteenth and twentieth centuries was also accompanied by particular understandings of 'how social lives should be mapped onto chronological time [becoming] enshrined in new laws and public institutions: childhood, youth, adulthood, and old age came to be viewed as distinct stages of life' (also see Johnson-Hanks 2002). Moreover, notions of school careers and adult (usually male) working careers became ubiquitous (Cole and Durham 2008: 6), with such visions of time and social ageing being promoted in many parts of the 'Global South' during the colonial and post-colonial periods (Ruddick 2003; also Comaroff and Comaroff 1991).

Furthermore, modernity also gave rise to a sense of acceleration and speeding up, as argued by Koselleck. This feature has also been highlighted in the spacetime compression that globalization gives rise to (Harvey 1990; Robertson 1992). Here acceleration seems to be one significant vector, where more information, digitalization and economic circuits pace expectations and hopes. People's hopes for better futures and particular futurities here are catapulted onwards (Virilio 1977; Eriksen 2001; Tomlinson 2008; Rosa 2013), and the ability to wait for one's turn seems to have become scarce in a technological landscape of immediacy. Thus, central perhaps to the contemporary experience of waiting is how it becomes intolerable with the technological and digital ways of speeding up social relationships, for instance, via mobile phones, Twitter, Facebook and Snapchat. Here we also see the growth of possibilities of civic strife and conflict, when imaginaries are fed by both corroborated as well as uncorroborated rumours (e.g. the recent emergence of the phenomenon of 'fake news') that demand action. The exhaustion of such imaginaries has the corollary in the late modern sense of crisis and fatigue, and even a loss of perspective. David Scott draws on some of the same insights when, in Omens of Adversity, he talks of the Grenada 
revolution gone awry (2014). For moderns, Scott posits, temporality has been revolving around the unfolding of historical time that is a progressive succession of instants. Here even secular Enlightenment has a particular conception of change as tied to fulfilment, as Scott says (2014: 5): 'Secular Enlightenment change is pictured as temporal movement in which, with regular periodicity, the future overcomes the past, and in which the present is a state of expectation and waiting for the fulfillment of the promise of social and political improvement.' However, this mood or anticipation of a better and more just time to come has been paused, and more pessimistic sentiments have emerged and taken hold in recent years, so much so that in Japan, for instance, this has even led to the emergence of 'Hope Studies' (Hage 2016; also see Miyazaki 2004, 2006). We are left with what Scott calls 'aftermaths'. In a similar vein, Janet Roitman talks of crisis as being the recent figure of thought, but crisis not as a moment in time but rather an extended condition (2014). Therefore we find a reversal of the classic meaning of crisis as a point of decision to an extended situation of indecision. Modernity, therefore, while presenting possibilities for human planning and prognosis also elicits fundamental doubts and misgivings (Arendt 1993 [1968]: 54; Bear 2014), which we now turn to.

\section{Doubt, uncertainty and hope}

One of the central insights of this book is that waiting as a phenomenon is an unstable object. Waiting is not to be found merely in the absence of action but in an uncertain terrain where what is hoped for may or may not occur. Periods of waiting release diverse affects ranging from hope, enthusiasm and urgency to apathy, paralysis and lethargy. As a consequence, waiting opens up for a variegated field of responses, or to follow up on Marcel's (1967) argument at the beginning of our Introduction, a range that goes from inert and passive waiting to active waiting. This in Gasparini's work (1995: 29ff.) leads to a focus on the semantic range of the term 'waiting. He sees a fundamental interrelatedness between 'waiting' and more or less marked forms of attention. Whatever has placed an individual or a collective in a situation of waiting, such a situation elicits diverse attitudes, and often leads to existential questions and doubts. Hence, an exploration of the figures of doubt, uncertainty and hope is critical for us to better conceive of waiting as a social phenomenon.

Hage has, in several of his works, interrogated the ways hope, struggle and movement impact on the sense of well-being of individuals as well as collectives. 
He examines the search for hope alongside the feelings of being 'stuck' and devoid of options to change one's predicament (Hage 2003), with stuckedness characterized by invisibility, immobility, uncertainty and arbitrariness. Here Hage accords a central place to the notion of existential mobility as a way of understanding various forms of movement (Hage 2005). Hence it is critical that one feels that one is moving somewhere in life, and the lack of such prospects may force actual physical movement to happen (see Mains 2007). Accordingly, both active and passive forms of waiting are important to interrogate also amidst current forms of crisis and dystopia (Hage 2009, 2015; also see Eriksen and Bendixen, this volume). In Hage's terminology there is an important marking out of such diverse forms of waiting, in his play with the prepositions following on from waiting. Are people waiting for something or are they waiting out their given travails. In his formulation (2015: 41): 'Waiting out is a specific form of waiting where one is not waiting for something but rather waiting for something undesirable that has to come, like a spell of cold weather or a disliked guest, to end or to go.' Therefore, Hage sees the potential for radical forms of change and revolutionary action as waning, where the new heroes are paragons of resilience, and frequently less inclined towards progressive politics, thought and revolutionary change.

Like waiting, doubt is a theme that has seldom figured prominently in the anthropological literature as an object of inquiry in its own right. Conversely, the disciplinary record abounds with studies of people's beliefs, ideologies and convictions, and - more recently - ontologies. It seems that through the years it has been more prevalent to describe and theorize figures such as these as relatively stable rather than to interrogate their formation as uncertain and labile forms of becoming (Engelke 2005; Taussig 2006; Bandak 2012; Pelkmans 2013; Bubandt 2014). For our purposes here, what we need to unravel are the relations between doubt, uncertainty and hope vis-à-vis waiting. Doubt and uncertainty unfold in the temporal sequences that are untied from a certain outcome. This is precisely what the relationship to time and expected ends affords when actors are waiting. To be sure there are a lot of things that we take for granted in that we do not even register them as embedded in our experience of waiting. Waiting for one's tea to brew during a working day may not present a particularly uncertain outcome; it may rather offer a welcome break for a couple of minutes where one relaxes before resuming work. Such forms of waiting for quotidian things may not therefore release doubt or uncertainty for most people. They are seen as routine matters.

When such routines are broken, matters may unfold otherwise or some rather different emotions may emerge. If we are used to a computer starting up 
within a period of time we have come to perceive and expect as reasonable, it can be enormously frustrating, infuriating even, to have to wait for the machine to restart due to new updates or if the hard drive is hard pressed. In such a situation, even if we may be talking about just a few seconds or moments spent waiting, it can feel like forever. What we learn from such a mundane example, which probably will be recognizable to most readers, is that clock time and experienced time rarely coincide. Unexpected waiting most often can be experienced as irritating, as if time itself is stretched out and prolonged. On other occasions, time seems to fly at a pace we cannot really comprehend. Such forms of experienced rapidity are often found in the face of making more serious decisions, situations where one could have asked for more time (cf. Flaherty 2011; Frederiksen and Dalsgård 2014). Furthermore, there are situations such as the one discussed by Schweizer (2008: 121), which describes the experiences of waiting endured by the parents of a dying boy, to illustrate a waiting for 'that which (cannot) be waited for', where 'waiting is simply an endurance of time that falls away from illusory circuits of meaning and intent' (Bissell 2009: 411).

This disjuncture between clock time and experienced time was profoundly captured by the French philosopher Henri Bergson (1859-1945) in his two first books, Time and Free Will (1913 [1889]) and Matter and Memory (1988 [1896]). Bergson aptly formulated the distinction between these forms of time as a matter of the duration and the physicist's time (1988 [1896]: 272): 'The duration lived by our consciousness is a duration with its own determined rhythm, a duration very different from the time of the physicist.' In contrast to the positivist ideals reigning at the time, Bergson in his early works examined how human perception never exists in empty space. It rather exists in a time already saturated with memories. Time as experienced by the human consciousness is marked as duration in time. Bergson makes a central distinction between qualitative and quantitative orderings of time, and places movement as a central component in time experience as it attests both to mental as well as mechanical forms of direction. Bergson accordingly sees various emotional attitudes as related directly to time. Sorrow, joy and hope, in this conception, are all related to either open or closed vistas, where duration is freely oriented towards the future or is sealed off, bound to the past. Social time, therefore, is not to be equated with measurable time units but rather as an experiential dimension of social life, which may only partially be measured by the watch and clock time (see also Gell 1992: 286ff.; Munn 1992: 94ff.; Hodges 2008; Schweizer 2008).

Tim Ingold formulates a similar insight in his phenomenological anthropology: 'In a sense, clock time is as alien to us as it is to the Nuer, the only difference is 
that we have to contend with it' (2000: 338). What Ingold brings home is that human beings rarely orient themselves to abstract time; they are instead oriented towards activities and socially informed tasks. In Ingold's conception, however, this insight also comes packaged with a romanticized notion of experiential time. In his preoccupation with experienced time, clock time appears to be marking only the alienation of human beings and outer representational schemes of temporality. This may be too general a perspective, as clock time and temporal regulations can also be productive in giving direction and impetus to complete one's endeavours. Deadlines can, as many of us know, cause unease and guilt (Rosa 2013) but also encourage productivity, the thrill and excitement of getting things done, and even at times generate energizing-accelerative moments of research conduct, thought and serendipitous discoveries (cf. Bachelard 2000: 88; Vostal 2015) or the experience of work as flow (cf. Csikszentmihalyi 1992; Ingold 2000).

A more ethnographically informed analysis may reveal how the concrete experience of time also relates to what is in one's own hands and what is beyond. A significant avenue of studies in this regard has been found in the engagement with prisons: what Avery Gordon designates as 'prison time' (2011), and what Adam Reed has termed as 'hope on remand' (2011). In these respective works, we see different configurations of time and hope with regard to what is perceived as the immanence or indeterminacy of waiting. In Reed's work on Bomana, the largest penal institution in Papua New Guinea, there is a marked difference between convicts and those on remand. Before the trial, remand inmates prepare for their case and cling to the hope of not ending up with a longer spell in prison. Consequently, they focus on the near future and attend to signs that may allow them to read the most likely outcome. On remand, most live in the hope of a positive outcome of their trial. However, when the sentence is delivered, life is transformed, and those having their future decided as proper inmates live with altogether evanescent forms of hope. Or as Reed (2011: 541) concludes: 'Wearing the prison uniform, shaved, and with hair cut short, they are often unrecognizable from the men I knew on remand. Abandoned by hope, they become hopeless.' Drawing on Hage, Reed sees this as a difference between waiting for and waiting out. Before the trial, the perspective is not closed and one can actively imagine a life outside the confined space of the prison; this perspective is transformed when the sentence is given. Similarly, Gordon describes how fate and fatalism are recurring figures in a US prison context, where prisoners are rendered as people without futures, forced to live in what is made to look like an incessant repetition of the same routines, of endless sameness (2011: 13-14). Here the 
penal system robs the incarcerated of their space as well as their time and control of when to carry out many of life's most intimate details. The relation to time changes, and this happens most frequently also in relation to the length and perspective of the sentence given.

What we see here is that the sense of control over time and space also elicits various forms of responses. As long as there are things to plan for, things that one believes or hopes will affect one's circumstances, activities seem filled with purpose and direction. When this is no longer the case, mundane chores and activities can be perceived as tedious and boring. The figures of repetition, monotony, tedium and boredom are hence prevalent figures when life does not seem to have a purposeful direction (Mains 2007; Schielke 2008; Frederiksen 2013; Kublitz 2016). Boredom experienced by young unemployed men in urban Ethiopia, for instance, as unstructured, potentially dangerous, and overabundant time to be 'passed' or 'killed', and as an inability to 'progress in the form of desirable social relations with others', can cause stress, depression, unease and frustration (Mains 2007: 666-667). Such situations may, however, not only be framed as corrosive, but may also be conducive to thought and creativity (also see the section below on Waiting as a method). Situations of waiting also have the potential to create novel forms of socialities, rituals and gendered sociabilities (Hoek 2014; Hussain 2014; Jeffrey 2010a, 2010b; Mains 2007; Cook 2014). Waiting can generate 'waithood' (Honwana 2012) - the combination of 'wait' and 'adulthood' - as an undefined period in young Africans' lives for instance, suspended between childhood and effective adulthood in its socially expected form, during which youth engage in creative ways of interacting in society, ranging from survival strategies to criminal activities (Honwana 2012; Honwana and De Boeck 2005). Waiting can constitute an active attempt to invest in and realize imagined, and at times incommensurable, futures (Chua 2014; Ibanez-Tirado 2014; Kwon 2015), a kind of future-making strategy, and 'skilful waiting' that can produce 'temporal subjects' suited to the speed and contingencies of late capitalism (Chua 2011: 117, 131). Conversely, urgency, impatience and haste may be seen in situations where serious diseases such as cancer require treatment, where one may not be able to afford waiting for test results (Day 2015). The waiting room in a hospital - one of the associated images that the cover of this book brings to mind - therefore emblematically attests to the various imaginings elicited by such waiting time. The scenarios and prospects of what the actual wait will lead to, therefore, work back on the present situation, and this only more so when time is a critical factor in treating an afflicted person or an emergency. 
A central theme that arises here is that of control (Gasparini 1995): who is able to act on time, and who is acted upon. In the work of Arendt and also Michael Jackson it is the capacity and experience of being able to act, and being acted upon, that is pivotal to a sense of well-being as well as agency (Arendt 1998; Jackson 2002, 2005; cf. Janeja 2010; also see Allison, this volume). Here some element of planning and a sense of control over one's time are important but rarely does one encounter a social situation that can be tamed completely. Schwartz's (1974: 858) distinction between waiting for and waiting on is instructive here. Waiting for describes a situation such as being stuck in a queue where one has little power vis-à-vis an institution, when there are scarce resources that result in waiting times coinciding with how power is distributed (Schwartz 1974). Waiting on, however, is choosing when to wait and when to act, a momentary 'putting to one side', a type of waiting that indexes agency. Building on this insight, Minnegal (2009: 91) writes: 'We wait on other subjects. There is always an interlocutor in such waiting [...] And the performance that results from this engagement is crucially shaped by the way that waiting - as reciprocal attention - is exchanged.' Thus, in the relational worlds we inhabit, we find an uncertain interplay between control and its lack, between a politics and poetics of waiting. It is our contention that anthropology is well equipped to explore this interplay, as waiting is also integral to the ethnographic method fundamental to our discipline.

\section{Waiting as a method}

At the very outset of this Introduction, we drew attention to the fact that waiting as an ethnographic 'object' in social and cultural anthropology has long been waiting, until recently, to be addressed in its own right. Paradoxically though, since its very inception, the anthropological enterprise has hinged on waiting as a tool and method, with Malinowski's waiting (albeit a form of forced waiting) on the Trobriand Islands becoming transformed into ethnographic fieldwork, grounding his now classic work and ethnographic texts, which have been foundational to the discipline itself. It would, therefore, be worthwhile to reflect on the implications of this legacy for the craft of anthropology. At times, the most important insights arise out of serendipity, from which 'good' ethnography and engaged anthropology come about. Such reflections are pertinent here since the anthropologically ethnographic method rests on various modalities of waiting; as anthropologists we work, plan and deal with the unexpected but also wait, in the conduct of our fieldwork and the crafting of our analyses. 
Ethnography, and what we call ethnographic waiting, takes place both in time and also as a relationship to time(s). Ethnography emerges in and by waiting: not just waiting out time but a skilled form of waiting as 'active and intentional' (Bissell 2007), 'an active, conscious, materialized practice' in which new ideas, strategies and actions are forged, 'in which time and space often become the objects of reflection' (Jeffrey 2008: 957). 'Doing' ethnography entails variegated forms of waiting - waiting for research funding to materialize; waiting for interlocutors to show up while engaging in fieldwork as 'deep hanging out' (Geertz 1998); waiting for the serendipitous - that which is valued because it cannot be predicted either in the conduct of fieldwork or in the process of writing. Ethnographic waiting also includes short, medium and longer term engagements with field notes (and head notes/mind notes, filed notes, older field notes; see, for example, Sanjek 1990; also see Whyte 2013); letting ideas, projects and questions in waiting mature (like old wine and ripened cheese), and arranging and 'purifying' them in the form of longer or shorter written ethnographic texts such as monographs or articles; conducting longitudinal research - 'itself a form of waiting' (Jeffrey 2008: 957). These various configurations of waiting across multiple spatiotemporal scales are constituted by a plurality of actions and inactions, processes, practices and perceptions, variegated stances or energies of hope, boredom (Dunn 2004; Driessen 2013; Sjørslev 2013; also see Bielo and Coleman in this volume), anxiety, doubt or uncertainty, that always hold the tantalizing potential of unfolding in other ways. The temporal trajectories of ethnographic waiting entail oscillations between these various processes, practices and stances, and ethnographic theory, practice and writing as craftsmanship are emergent in these very oscillations. Clara Han's insightful study of waiting as care, which uses longitudinal ethnographic research (1999-2008) in a working-class neighbourhood in Santiago, is instructive here. Following a poor extended family, her study shows how women make lateral uses of credit taken from beyond the home to generate a time for waiting within it, enabling them to care for mentally ill and addicted kin through this active waiting that draws its hope from 'the possible' (2011: 8-9,25), although the limits of such care through the temporality of infinitely responsive waiting are also manifested in, for instance, forms of domestic violence and illness. Methodologically, she argues, 'How we, as anthropologists, come to see [...] fleeting moves, [...] small affective enactments and temporary destructions of a world, depends in large measure on our own movement in time with those with whom we work' (2011:26).

Thus, the 'ethnographic self' enmeshed simultaneously in precarious networks of waiting and speeding up across variegated scales needs to be addressed. On 
the one hand, there are the transformations elicited by the corporeal practices of waiting and the bodily demands made by a plethora of technologies such as laptops, iPads, smart phones and so on, that the contemporary ethnographer has come to rely upon. Such technologies are used to arguably facilitate productive mobile forms of waiting while in transit at 'non-places' (Augé 1992) such as airports, en route perhaps to the next field-site or conference, and may crystallize in another paper abstract being sent off, the final sentences of an ethnographic text suddenly 'making sense', the umpteenth email 'being done', or another 'ethnographic moment' (Strathern 1999) being snapped up on a smartphone camera. However, the very technologies that are supposed to speed things up for the ethnographer, to eliminate waiting so as to save time and offer reassurance and security, instead bring forth unpredictable and unanticipated forms of waiting: waiting for the turning wheel on the computer screen to stop, the waiting for things 'to load', the frustration and anxiety when the internet connection or the 'back-up' do not work, and one has to call the computer 'helpdesk' but an automated voice tells us we are 'in the queue' and 'thanks' us for our 'patience'. The speeding up of ethnographic waiting has not necessarily led to a shrinking but rather a proliferation of emergent modes of waiting. ${ }^{7}$

On the other hand, the increasing regimentation and bureaucratization of time, the 'explosion of audit cultures' (Powers 1999; Strathern 2000) and their growing reach in the form of 'outputs', 'excellence', and the 'impact factor' constantly measured anew (Burrows 2012; Vostal 2015) - across disciplines including anthropology and the academic profession more generally (e.g. Ylijoki and Mäntylä 2003; Levy 2007; Berg and Seeber 2016) - have changed the nature of anthropological craftsmanship's relationship to the temporal rhythms of waiting. The temporalities of waiting critical to - the translation of data into information, and further into knowledge; the deliberate and patient production of ethnography; the processes of imagination, flight, maturation or 'the nesting of ideas' (Benjamin 1999: 90; cf. Bandak and Kuzmanovic 2015) and retrospection as fundamental to analysis; the transformation of ethnographic boredom into productive engagement - have been increasingly put under pressure in a neoliberal era where people are not being allowed to wait. With everything being accelerated vis-à-vis productivist discourses of speed and efficiency, we are being compelled (or are we?) to unlearn the craft of close attention and the conventions of attending to something with patience. Instead we are increasingly being pushed into a hurried disdain for detail that reins in the freedom to think, fences in the imagination, and undermines, or at least works contrary to, sedimented forms of learning and emergent knowledge-making. 
Ruptures of the traditional ideals of the temporalities of waiting in anthropological research and challenges to the explicit norms and forms of the doing of ethnography are analysed by George Marcus (2013) in the following manner. He highlights various sources of anxiety regarding the relative slowness of ethnography in the constantly shifting space-time contexts and emergent assemblages of sites, things and persons that characterize a now growing 'anthropology of the contemporary' (cf. Rabinow 2008; Rabinow et al. 2008). Firstly, the desire to be relevant to various publics beyond those specific publics - that are defined by the process of ethnographic research itself and to which anthropology could more realistically aspire to be relevant - creates pressures on the norms and practices of a temporality of patience pivotal to the identity of being an ethnographer. It makes the ethnographer anxious about the belated forms in which ethnographic results are produced, 'belated' since 'the pacing and tempo by which ethnography is produced still conforms to the traditional norm of taking one's (almost unlimited) time' (Marcus 2013: 149-150; parentheses in the original). Secondly, the conflicts of temporalities in key collaborative relationships of ethnographic work in an anthropology of the contemporary is another dimension of the ethnographic anxiety of being relatively slow, e.g. a lawyer or consultant counterpart of the ethnographer may harness a significant concept or insight far more quickly than the ethnographer who may want to 'take her time' to develop it. Given the rise of 'the present professional culture for the production of ethnography' thus outlined, Marcus also draws attention to the predicament that many anthropologists of the contemporary, especially younger scholars starting their careers, find themselves in by taking up a topic that has 'already been more prominently and promptly treated by other media', which makes it necessary for them to take into account these complex preexisting 'zones of overlapping representations' as well as to find ways of becoming 'comfortable with their inevitable belatedness' as ethnographers (Marcus 2013: 151-152). These various anxieties and challenges notwithstanding, the norms of a temporality of patience are still formally in place and continue to underpin the standards of conventional professional review. However, Marcus (2013: 153-154) offers a way out, and upholds Kim Fortun's innovative and thoughtful responses, both in the practice of fieldwork and ethnographic writing, as instructive in navigating this conundrum. Following her doctoral dissertation, Fortun did not publish - until 2001 - her ethnographic monograph, Advocacy After Bhopal, which draws on fieldwork at the Bhopal site conducted in 1988-1989, during the period of settlement after the Bhopal disaster that occurred in 1984. She uses the 'medium-term' temporal frame (drawing on Ulf Hannerz' notion of 'medium- 
term history') to conceptually create a past-present-emergent time-space within which her account operates as an effective strategy for negotiating the necessary slowness of ethnographic research with the threat of ethnography's permanent belatedness in relation to its object' in producing an ethnography of the contemporary.

Marcus' hopeful entreaty to anthropologists resonates with the patient resilience of Penelope as well as with Procupez's argument on collective patience as a long-term perspective, an active engagement with, and as a collective disposition towards, inhabiting time that combines both urgency and restraint. To go back to Procupez's formulation, patience here is 'waiting while working to make something happen, it is (reluctant) hope...' (2015: S63; parentheses in the original). The ambivalences, uncertainties, doubts and intensities that are at the core of hope (Miyazaki 2010; Hage 2016), the potentialities of the unexpected and the otherwise, call for a pragmatic exercise of care and vigilance. A careful and vigilant waiting - in its modalities of hope, patience and resilience - offers ways of negotiating the challenges and pressures on the norms and forms of anthropological ethnography highlighted. Driven by passion and compassion, careful and vigilant waiting as a method may offer another way forward for anthropology.

\section{Engaging with waiting through ethnography - on the contributions}

As argued above, ethnography shares an integral relationship to waiting as a method. Owing to this engagement with waiting, anthropologists have a repository to draw upon when focusing on waiting as an 'object' of enquiry. In, and through, ethnography it becomes clear how waiting can be used as a prism to understand the ways in which temporalities and social relationships emerge and are being reconfigured in diverse social and cultural contexts. The ambition of this volume is therefore to open up for nuanced perspectives on how people wait differently, be that across various cultural contexts or within the same setting, and how waiting as such affords variegated potentials also for the same persons at different junctures, in various locations and situations. Thus, what the contributions offer are a set of sustained meditations on the forms and modalities of waiting.

While some of the contributions draw on the theme of religion and Christianity, others attend to contexts where neither religion nor a sense of 
purpose can be said to permeate the wait. Likewise, some of the chapters present ethnographies where waiting is tied to political or financial decisions made by others, while other chapters present us with cases where the choices and decisions are pending but are to be made by the actors themselves. Thus, the array of ethnographies, rather than foreclosing a particular avenue for engaging with the concept of waiting, attests to the interplays between the politics and poetics of waiting. The central insight is that nuanced ethnographic analyses call for an engagement with a range of interplays between these dimensions, without according analytical primacy to either of them. We need to keep the figure of waiting open to acquiring variegated forms and modalities in diverse social and cultural contexts. And we need to remain open to the ways in which waiting may be performed and experienced differently. The ethnographies in this volume attest to the ways in which the poetics of waiting are intertwined with the politics of waiting, and furthermore, that in some cases this dimension may be what asks for more focused attention. Rather than positing this as a general conclusion, it serves more as a call for keeping open both ethnographies of waiting, and their inherent and uncertain interplays between multiple modalities of waiting.

In Simon Coleman's chapter, we are presented with an astute analysis of both Coleman's own experiences of growing up in Jewish London and then his fieldwork on charismatic Christians in Livets Ord, Uppsala, Sweden. The cases are used to reflect the ways ethnographer and interlocutor alike are presented with moments where ritual may not work smoothly but rather be marked by boredom, inattendance and unfocused presence. However, where inattention in Coleman's Jewish context may be what keeps the ritual working, such inattention may also be conceived as a dangerous loss of performative edge, as his Swedish ethnography attests to. What Coleman therefore presents us with is how various forms of waiting may lead to rehearsed forms of patience but also a striving to activate the potential of the now in seizing future possibilities. Curiously, such local corollaries of waiting help Coleman to engage both his ethnographic attention as well as to situate the ways boredom may not just be an inherent danger in waiting but also what opens up for different potentials and emergent forms of becoming.

Where Coleman presents a case of both Christian and Jewish forms of waiting, Jarrett Zigon in his chapter presents us with an ethnography of hope and waiting in Post-Soviet Moscow. In Zigon's chapter, we are presented with two forms of hope among his Muscovite interlocutors. The first is a passive form of hope, which locally is conceived as close to a mere waiting for things to happen. The second, by contrast, is an active form of hope where one has to work in order 
to arrive at what is hoped for. In other words, one may live in a situation where the objective conditions do not leave much hope but, in order to live ethically, hope can never be surrendered. Risk and courage are inherent features of such forms of hoping, as Zigon's ethnography reveals. This chapter then contributes with a hermeneutic of hope that illuminates two dimensions of hope: active and passive. This interplay between the passive and active modalities is found in the manner in which waiting allows for hope to fashion a way of living amidst precarious conditions.

Synnøve Bendixsen and Thomas Hylland Eriksen in their contribution explore Palestinians in Oslo and their ways of acting on time and their situation of empty liminal being. The Palestinians in focus are categorized as irregular migrants, which places them beyond the pale of legal entitlements of refugees in the Norwegian system. The contribution therefore adds to the growing literature on migration and forms of waiting by not only attesting to the subjugation to time found in the situation where Palestinians await political decisions made by the welfare state, but also highlighting where they attempt to transform their wait into an active state of being, by moving outside the asylum centres to a clandestine camp in central Oslo. In this sense, Eriksen and Bendixen shed light on attempts at reordering empty and meaningless time in order to give it direction and scope. They also show that such attempts at giving shape to time, often by those without power, may be a rather frail and difficult exercise, which may lead from activity to passivity if hope is persistently thwarted.

Where many of the contributions to this volume present us with ethnographies where the waiting may be either for terrible things to come or for ways to live with or avoid boredom, James Bielo presents us with a compelling case of innovation, and the impact of withheld funding on creative processes among his interlocutors on the Ark Encounter, Kentucky. It was long planned that a creationist theme park would feature a life-sized Noah's ark, allowing visitors a vivid experience of the biblical past. However, for more than twenty months the process stalled, and the entire funding was cast in doubt, before the park finally opened in July 2016. It was in these uncertain months when the creative team was waiting for news on the funding, and hence stalling with the creative ambitions, that Bielo was allowed to do fieldwork with them. This period was hence one of delay, and one where further fundraising activities brought alternative scenarios into play, what Bielo aptly designates as a creative ceiling. The chapter reflects the interplay between Bielo's own waiting and that of the creative team, caught in the tedium and stalling of the process. What this ethnography illuminates is 
that learning and innovation also come about while time is 'wasted' and doubt seems pervasive.

In Bruno Reinhardt's chapter, we are introduced to a set of engaged forms of waiting among Charismatic Christians in Ghana. Reinhardt explores the practice of prayer in his ethnography, where prayer is seen as an active state of anticipation on the part of his ardent Christian interlocutors. He situates his case as a set of entanglements between Pentecostal and post-colonial temporalities. Here the cue is taken from Marcel Mauss' work on prayer as inherently socially oriented but also from his insight that collective waiting amounts to a state of anticipation. Drawing on these in the Ghanaian context, Reinhardt argues that an active waiting for God is instrumental in fashioning endurance and steadfastness in the face of crisis, and acting upon it. Through the active engagement with prayer the Ghanaian Charismatic Christians inhabit not just a crisis-ridden landscape but also one of emergent virtual futures in which they read the signs of God's intervention and blessing. To wait for God here does not mean a passive surrender but an active giving over of one's circumstances and fostering a patient but receptive Christian form of personhood.

Whereas in many of the chapters we encounter forms of waiting that are experienced as problematic or meaningless, it is also possible to interrogate the idea of waiting as being an interim or a pause before a more meaningful situation can be resumed. It is just such a situation we encounter in Martin Demant Frederiksen's contribution on nihilists in Tbilisi, Georgia. For the nihilists, we are presented with meaninglessness, as not a temporary situation but rather a pervasive one, where there is no incentive to find a purpose of waiting. It is rather a wait without waiting that Frederiksen hones in on, and asks us to consider. We are thus pushed to go beyond waiting as a category that people necessarily work to abolish. We may find situations where some work actively towards suspending any ascription of purpose or meaning to life as such. Accordingly, a rather different sense of temporality becomes visible here, one that flies in the face of scenarios of both progress and crisis.

A different form of waiting is found in Anne Allison's chapter on those in Japan who live in isolation from society, awaiting their own departure from this life. In their ways of dealing with their impending death, they attest to some pertinent features of late modernity in that individualization may go hand in hand with attempts at controlling one's reputation and legacy. In the Japanese context, a cultural ideal of not being a burden to others is seen in the ways in which one can prepare for one's own death. Here waiting is transformed into preparation, and control over the last imprint left on one's life and destiny. 
Waiting, in Allison's ethnography then, becomes a not-waiting, an active form of seizing life and controlling what is left for the future.

To return to our opening remarks, what we hope to have shown is how the very question of whether something is worth the wait is what mobilizes an openended scrutiny and exploration of social and cultural life. What we therefore call for is not only more ethnographic work on waiting but also fresh pathways that invite further exploration of the ways in which variegated temporal configurations elicit hope, doubt, boredom and anticipation. Ethnography here is a particular experience of being given over to waiting, but also of using such forms of waiting creatively. This is when the wait may be turned into something of worth for the human condition in all its diversity.

\section{Notes}

1 At the time of going to press, Shahram Khosravi's (2017) ethnography on Precarious Lives: Waiting and Hope in Iran was also published.

2 Waiting underpins Bourdieu's argument on time as a resource, in Outline of a Theory of Practice, where he re-examines the question of reciprocity and gift-giving: he argues that holding back a gift - and thus making the recipient wait - is central to how power relations and strategies unfold between individuals as well as collectives (1977). However, temporality also plays a central role in Bourdieu's later work, particularly in Pascalian Meditations. In this work, he delineates the 'presence of the forth-coming' as a relationship between anticipated outcomes and the logics of the game, between expectations and chances (2000: 208ff.), and unravels what happens when the coincidence between these is not fulfilled, thereby giving 'rise to relations to time such as waiting and impatience' (2000: 209).

3 This section also draws on our research interests in the themes of migration, forms of social diversity and urban inequality in the Middle East, South Asia and Europe.

4 Several anthropological studies focus on the issue of a temporal orientation toward a permanent timeless present, e.g. Buch (2013), Day et al. (1999), Thomassen (2014) and Khosravi (2014).

5 As Blanchot (1981) notes, patience and impatience are constitutive of each other. Also cf. Marcel (1967: 280).

6 Several anthropologists have recently introduced Alain Badiou and his work on the event (Humphrey 2008; Bear 2014). Badiou also explores the figure of Paul in his work as a figure who propagates the message of universalism and bespeaks a model of the event and fidelity towards it (2003 [1997], but also see Bialecki 2009; Engelke and Robbins 2010). However, Agamben here (2005 [2000]) follows the Jewish 
philosopher Jacob Taubes, and his reading of Paul as a Jewish thinker (2004 [1993]), in order to explore the figure of temporality and the ending of time, which is more pertinent to our engagement with the figure of waiting.

7 We are grateful to David Goldberg for drawing our attention to this.

\section{References}

Abram, Simone and Gisa Weszkalnys. 2011. 'Introduction: Anthropologies of Planning

- Temporality, Imagination, and Ethnography’. Focaal - Journal of Global and

Historical Anthropology 61: 3-18.

Agamben, Giorgio. 2007 [1978]. History and Infancy. On the Destruction of Experience.

London: Verso.

Agamben, Giorgio. 1998 [1995]. Homo Sacer. Sovereign Power and Bare Life. Stanford,

CA: Stanford University Press.

Agamben, Giorgio. 2005 [2000]. The Time That Remains. A Commentary on the Letter to the Romans. Stanford, CA: Stanford University Press.

Agier, Michel. 2002. 'Between War and City: Towards an Urban Anthropology of

Refugee Camps'. Ethnography 3(3): 317-341.

Andersson, Ruben. 2014a. 'Time and the Migrant Other: European Border Controls and the Temporal Economics of illegality'. American Anthropologist 116(4): 795-809.

Andersson, Ruben. 2014b. Illegality, Inc. Berkeley: University of California Press.

Appadurai, Arjun. 2002. 'Deep Democracy: Urban Governmentality and the Horizon of Politics'. Public Culture 14(1): 23-43.

Appadurai, Arjun. 2013a. The Future as Cultural Fact. Essays on the Global Condition. London: Verso.

Appadurai, Arjun. 2013b. 'Housing and Hope'. Places Journal (March 2013). https://doi. org/10.22269/130305. (accessed 30 June 2017).

Arce, Alberto and Norman Long. 2000. Anthropology, Development and Modernities:

Exploring Discourse, Counter-Tendencies and Violence. New York: Routledge.

Arendt, Hannah. 1990 [1963]. On Revolution. New York: Penguin Books.

Arendt, Hannah. 1993 [1968]. Between Past and Future. Eight Exercises in Political

Thought. New York: Penguin Books.

Arendt, Hannah. 1998 [1958]. The Human Condition. Chicago: University of Chicago

Press.

Asad, Talal. 1993. Genealogies of Religion. Discipline and Reasons of Power in

Christianity and Islam. Baltimore and London: Johns Hopkins University Press.

Augé, Marc. 1995 [1992]. Non-Places. Introduction to an Anthropology of

Supermodernity. Translated by John Howe. London: Verso.

Auyero, Javier. 2012. Patients of the State: The Politics of Waiting in Argentina. Durham,

NC: Duke University Press. 
Bachelard, Gaston. 2000 [1936]. The Dialectic of Duration. Translated by Mary McAllester Jones. Manchester: Clinamen Press.

Badiou, Alain. 2003 [1997]. Saint Paul. The Foundation of Universalism. Stanford, CA: Stanford University Press.

Bandak, Andreas. 2012. 'Problems of Belief: Tonalities of Immediacy among Christians of Damascus'. Ethnos: Journal of Anthropology 77(4): 535-555.

Bandak, Andreas and Daniella Kuzmanovic. 2015. 'Introduction. Analytical Displacement and the Project of the Humanities'. In Qualitative Analysis in the Making, edited by Danielle Kuzmanovic and Andreas Bandak, 1-24. New York: Routledge.

Bayart, Jean-François. 2007. Global Subjects: A Political Critique of Globalization. Cambridge: Polity.

Bear, Laura. 2014. 'Doubt, Conflict, Mediation: The Anthropology of Modern Time'. Journal of the Royal Anthropological Institute 20(S1): 3-30.

Benjamin, Walter. 1999 [1968]a. 'The Storyteller. Reflections on the Works of Nikolai Leskov'. Illuminations. London: Pimlico, 83-107.

Benjamin, Walter. 1999 [1968]b. 'Theses on the Philosophy of History'. Illuminations. London: Pimlico, 245-255.

Berg, Maggie and Barbara Seeber. 2016. The Slow Professor. Challenging the Culture of Speed in the Academy. Toronto: University of Toronto Press.

Bergson, Henri. 1913 [1889]. Time and Free Will. An Essay on the Immediate Data of Consciousness. New York: Macmillan Company.

Bergson, Henri. 1988 [1896]. Matter and Memory. New York: Zone Books.

Bialecki, Jon. 2009. 'Disjuncture, Continental Philosophy's New "Political Paul," and the Question of Progressive Christianity in a Southern Californian Third Wave Church'. American Ethnologist 36(1): 110-123.

Bindé, Jerome. 2000. 'Toward an Ethics of the Future'. Public Culture 12(4): 51-72.

Bissell, David. 2007. 'Animating Suspension: Waiting for Mobilities'. Mobilities 2(2): 277-298.

Bissell, David. 2009. 'The Poetics of Waiting Without Value: Harold Schweizer, On Waiting. Time and Society 18: 410-413.

Blanchot, Maurice. 1981. The Gaze of Orpheus and Other Literary Essays. New York: Station Hill.

Hansen, Thomas Blom and Finn Stepputat. 2005. Sovereign Bodies: Citizens, Migrants, and States in the Postcolonial World. Princeton, NJ: Princeton University Press.

Boltanski, Luc. 1999. Distant Suffering. Morality, Media and Politics. Cambridge: Cambridge University Press.

Bourdieu, Pierre. 1977. Outline of a Theory of Practice. Cambridge: Cambridge University Press.

Bourdieu, Pierre. 2000. Pascalian Meditations. London: Polity Press.

Bredeloup, Sylvie. 2012. 'Sahara Transit: Times, Spaces, People'. Population, Space and Place 18: S. 457-467. 
Bubandt, Nils. 2014. The Empty Seashell. Witchcraft and Doubt on an Indonesian Island. Ithaca, NY: Cornell University Press.

Buch, Lotte. 2013. 'Enduring Presents: Living a Prison Sentence as the Wife of a

Detainee in Israel'. In Times of Security: Ethnographies of Fear, Protest and the Future, edited by Morten Pedersen and Martin Holbraad, 122-140. New York: Routledge.

Burrows, Roger. 2012. 'Living with the h-index? Metric Assemblages in the Contemporary Academy'. Sociological Review 60(2): 355-372.

Chakrabarty, Dipesh. 2000. Provincializing Europe: Postcolonial Thought and Historical Difference. Princeton, NJ: Princeton University Press.

Chua, Jocelyn Lim. 2011. 'Making Time for Children: Self-Temporalization and the Cultivation of the Antisuicidal Subject in South India. Cultural Anthropology 26(1): 112-137.

Chua, Liana. 2014. 'Juggling Time(s): Waiting for Inundation and Resettlement in Malaysian Borneo'. Paper presented on the panel Ethnographies of Waiting, ASA Decennial Conference, Edinburgh.

Clifford, James. 1986. 'Introduction: Partial Truths'. In Writing Culture. The Poetics and Politics of Ethnography, edited by James Clifford and George Marcus, 1-26. Berkeley: University of California Press.

Clifford, James and George Marcus. 1986. Writing Culture. The Poetics and Politics of Ethnography. Berkeley: University of California Press.

Cole, Jennifer and Deborah Durham (eds.). 2008. Figuring the Future: Children, Youth, and Globalization. Santa Fe, NM: School of American Research Press.

Comaroff, John and Jean Comaroff. 1991. Of Revalation and Revolution. Christianity, Colonialism, and Consciousness in South Africa, Volume 1. Chicago: University of Chicago Press.

Conlon, Deirdre. 2007. The Nation as Embodied Practice: Women, Migration and the Social Production of Nationhood in Ireland. Ph.D. Dissertation, City University of New York.

Conlon, Deirdre. 2011. 'Waiting: Feminist Perspectives on the Spacings/Timings of Migrant (Im)mobility'. Gender, Place and Culture: A Journal of Feminist Geography 18(3): 353-360.

Cook, Ian. 2014. 'Waiting and Waiting at the Edge of the Indian City'. Paper presented on the panel. Ethnographies of Waiting, ASA Decennial Conference, Edinburgh.

Corbridge, Stuart. 2004. 'Waiting in Line, or the Moral and Material Geographies of Queue-jumping. In Geographies and Moralities, edited by Roger Lee and David M. Smith, 183-198. Oxford: Blackwell.

Crapanzano, Vincent. 1985. Waiting: The Whites of South Africa. London: Random House.

Crapanzano, Vincent. 2003. 'Reflections on Hope as a Category of Social and Psychological Analysis'. Cultural Anthropology 18(1): 3-32.

Csikszentmihalyi, Mihaly. 1992. Flow. The Psychology of Happiness. New York: Harper and Row. 
Dalsgaard, Steffen and Morten Nielsen. 2013. 'Introduction. Time and the Field'. Social Analysis 57(1): 1-19.

Das, Veena. 2016. 'The Boundaries of the 'We': Cruelty, Responsibility and Forms of Life.' Critical Horizons 17(2): 168-185.

Day, Sophie E. 2015. 'Waiting and the Architecture of Care'. In Living and Dying in the Contemporary World: A Compendium, edited by Clara Han and Veena Das, 167-184. Berkeley: University of California Press.

Day, Sophie, Evthymios Papataxiarchis and Michael Stewart (eds.). 1999. Lilies of the Field. Marginal People Who Live for the Moment. Oxford: Westview Press

De Genova, Nicholas P. 2002. 'Migrant "Illegality" and Deportability in Everyday Life.' Annual Review of Anthropology 31: S. 419-447.

Derrida, Jacques. 2004. Specters of Marx. New York: Routledge.

Driessen, Henk. 2013. 'Suspense in Retrospective Ethnography'. In Ethnographies of Doubt. Faith and Uncertainty in Contemporary Societies, edited by Mathijs Pelkmans, 149-164. London: I.B. Tauris.

Dunn, Elizabeth Cullen. 2004. Privatizing Poland: Baby Food, Big Business, and the Remaking of Labor. Ithaca, NY: Cornell University Press.

Elliot, Alice. 2016. 'Paused Subjects: Waiting for Migration in North Africa'. Time \& Society 25(1): 102-116.

Engelke, Matthew. 2005. 'The Early Days of Johane Masowe: Self-doubt, Uncertainty, and Religious Transformation. Comparative Studies in Society and History 47(4): 781-808.

Engelke, Matthew. 2010. 'Past Pentecostalism: Notes on Rupture, Realignment, and Everyday Life in Pentecostal and African Independent Churches'. Africa 80(2): 177-199.

Englund, Harry and James Leach. 2000. 'Ethnography and the Meta-Narratives of Modernity. Current Anthropology 41(2): 225-239.

Eriksen, Thomas Hylland. 2001. Tyranny of the Moment: Fast and Slow Time in the Information Age. London: Pluto Press.

Eriksen, Thomas Hylland. 2016. Overheating. An Anthropology of Accelerated Change. London: Pluto Press.

Evans-Pritchard, Edward Evan. 1939. 'Nuer Time-Reckoning'. Africa: Journal of the International African Institute 12(2): 189-216.

Fabian, Johannes. 1983. Time and the Other: How Anthropology Makes its Object. New York: Columbia University Press.

Fassin, Didier. 2013. 'The Precarious Truth of Asylum'. Public Culture 69(1): 39-63.

Flaherty, Michael. 2011. The Textures of Time. Agency and Temporal Experience. Philadelphia: Temple University Press.

Fortun, Kim. 2001. Advocacy After Bhopal: Environmentalism, Disaster, New Global Orders. Chicago: University of Chicago Press.

Foucault, Michel. 1991 [1975]. Discipline and Punish: The Birth of the Prison. New York: Penguin Books. 
Frederiksen, Martin Demant. 2013. Young Men, Time, and Boredom in the Republic of Georgia. Philadelphia: Temple University Press.

Frederiksen, Martin Demant and Anne Line Dalsgård. 2014. 'Introduction. Time Objectified'. In Ethnographies of Youth and Temporatlity: Time Objectified, edited by Anne Line Dalsgård, Martin Demant Frederiksen, Susanne Højlund and Lotte Meinert. Philadelphia: Temple University Press.

Gaibazzi, Paolo. 2012. "God's time is the best": Religious Imagination and the Wait for Emigration in the Gambia'. In The Global Horizon, Expectations of Migration in Africa and the Middle East, edited by Knut Graw and Samuli Schielke, 121-135. Leuven: Leuven University Press.

Gasparini, Giovanni. 1995. 'On Waiting'. Time and Society 4(1): 29-45.

Geertz, Clifford. 1998. 'Deep Hanging Out'. New York Review of Books, 22 October, 69-72. Gell, Alfred. 1992. The Anthropology of Time. Cultural Constructions of Temporal Maps and Images. Oxford: Berg.

Giddens, Anthony. 1991. Modernity and Self-Identity. Self and Society in the Late Modern Age. Cambridge: Polity Press.

Gordon, Avery F. 2011. 'Some Thoughts on Haunting and Futurity'. Borderlands 10(2): $1-21$.

Graw, Knut and Samuli Schielke. 2012. 'Introduction: Reflections on Migratory Expectations in Africa and Beyond'. In The Global Horizon, Expectations of Migration in Africa and the Middle East, edited by Knut Graw and Samuli Schielke, 7-17. Leuven: Leuven University Press.

Gregory, Christopher A. 1982. Gift and Commodities. London: Academic Press. Griffiths, Melanie, Ali Rogers and Bridget Anderson. 2013. Migration, Time and Temporalities: Review and Prospect. Oxford: Centre on Migration, Policy and Society (COMPAS) Research Resources Paper.

Gullestad, Marianne. 2007. Picturing Pity: Pitfalls and Pleasures in Cross-cultural Communication - Image and Word in a North Cameroon Mission. Oxford: Berghahn Books.

Guyer, Jane. 2007. 'Prophecy and the Near Future: Thoughts on Macroeconomic, Evangelical, and Punctuated Time'. American Ethnologist 34(3): 409-421.

Hage, Ghassan. 2003. Against Paranoid Nationalism: Searching for Hope in a Shrinking Society. London: Pluto Press.

Hage, Ghassan. 2005. 'A Not So Multi-sided Ethnography of a Not So Imagined Community'. Anthropological Theory 5: S. 463-475.

Hage, Ghassan. 2009. Waiting. Melbourne: Melbourne University Press.

Hage, Ghassan. 2015. Alter-Politics. Critical Anthropology and the Radical Imagination. Melbourne: Melbourne University Press.

Hage, Ghassan. 2016. 'Afterword. Questions Concerning a Future-Politics'. History and Anthropology 27(4): 465-467.

Han, Clara. 2011. 'Symptoms of Another Life: Time, Possibility and Domestic Relations in Chile's Credit Economy'. Cultural Anthropology 26(1): 7-32. 
Hann, Chris and Herman Goltz. 2010. Eastern Christians in Anthropological Perspective. Berkeley, Los Angeles and New York: California University Press.

Harvey, David. 1990. The Condition of Postmodernity. An Enquiry into the Origins of Cultural Change. Malden, MA: Wiley-Blackwell.

Herzfeld, Michael. 1985. The Poetics of Manhood: Contest and Identity in a Cretan Mountain Village. Princeton, NJ: Princeton University Press.

Herzfeld, Michael. 2005. Cultural Intimacy: Social Poetics in the Nation-State. 2nd Edition. New York: Routledge.

Herzfeld, Michael. 2016. Cultural Intimacy: Social Poetics and the Real Life of States, Societies, and Institutions. 3rd Edition. New York: Routledge.

Hodges, Matt. 2008. 'Rethinking Time's Arrow. Bergson, Deleuze and the Anthropology of Time'. Anthropological Theory 8(4): 399-429.

Hoek, Lotte. 2014. 'Dhaka Jammed: Languages of the Jam, Spaces of the City'. Paper presented on the panel Ethnographies of Waiting, ASA Decennial Conference, Edinburgh.

Honwana, Alcinda. 2012. The Time of Youth: Work, Social Change and Politics in Africa. Washington, DC: Kumarian.

Honwana, Alcinda and Filip De Boeck (eds.). 2005. Makers and Breakers: Children and Youth in Post-colonial Africa. Trenton, NJ: Africa World Press.

Humphrey, Caroline. 2008. 'Reassembling Individual Subjects. Events and Decisions in Troubled Times'. Anthropological Theory 8(4): 357-380.

Hussain, Delwar. 2014. 'The People Wait: Elections and Violence in Contemporary Bangladesh'. Paper presented on the panel Ethnographies of Waiting, ASA Decennial Conference, Edinburgh.

Ibanez-Tirado, Diana. 2014. "We Sit and Wait”: Labour Migration and Temporality in Guliston, Southern Tajikistan'. Paper presented on the panel Ethnographies of Waiting, ASA Decennial Conference, Edinburgh.

Ingold, Tim. 2000. The Perception of the Environment. Essays in Livelihood, Dwelling and Skill. London: Routledge.

Jackson, Michael. 2002. The Politics of Storytelling. Violence, Transgression and Intersubjectivity. Copenhagen: Museum Tusculanum Press.

Jackson, Michael. 2005. Existential Anthropopology. Events, Exigencies and Effects. Oxford: Berghahn Books.

Janeja, Manpreet K. 2010. Transactions in Taste: The Collaborative Lives of Everyday Bengali Food. London: Routledge.

Janeja, Manpreet K. 2014. 'Waiting for Food'. Paper presented on the panel Ethnographies of Waiting, ASA Decennial Conference, Edinburgh.

Jeffrey, Craig. 2008. 'Waiting'. Environment and Planning D: Society and Space 26(6): 954-958.

Jeffrey, Craig. 2010a. Timepass: Youth, Class, and the Politics of Waiting in India. Stanford, CA: Stanford University Press.

Jeffrey, Craig. 2010b. 'Timepass: Youth, Class, and Time among Young Unemployed Men in India. American Ethnologist 37(3): 465-481. 
Johnson-Hanks, Jennifer. 2002. 'On the Limits of Life Stages in Ethnography: Toward a Theory of Vital Conjunctures'. American Anthropologist 104(3): 865-880.

Johnson-Hanks, Jennifer. 2005. 'When the Future Decides. Uncertainty and Intentional Action in Contemporary Cameroon'. Current Anthropology 46(3): 363-377.

Khosravi, Shahram. 2014. 'Waiting.' In Migration: the Compas Anthology, edited by Bridget Anderson and Michael Keith. Oxford: ESRC Centre on Migration, Policy and Society (COMPAS).

Khosravi, Shahram. 2017. Precarious Lives. Waiting and Hope in Iran. Philadelphia: University of Pennsylvania Press.

Koselleck, Reinhardt. 2004. Futures Past: On the Semantics of Historical Time. New York: Colombia University Press.

Kublitz, Anja. 2016. 'The Ongoing Catastrophe. Erosion of Life in the Danish Camps'. Journal of Refugee Studies 29(2): 229-249.

Kwon, June Hee. 2015. 'The Work of Waiting: Love and Money in Korean Chinese Transnational Migration' Cultural Anthropology 30(3): 477-500.

Latour, Bruno. 1993. We Have Never Been Modern. Cambridge, MA: Harvard University Press.

Lazar, Sian. 2014. 'Historical Narrative, Mundane Political Time, and Revolutionary Moments: Coexisting Temporalities in the Lived Experience of Social Movements'. Journal of the Royal Anthropological Institute 20(S1): 129-147.

Levy, David M. 2007. 'No Time to Think: Reflections on Information Technology and Contemplative Scholarship'. Ethics and Information Technology 9(4): 237-249.

Lindquist, Galina. 2006. Conjuring Hope. Healing and Magic in Contemporary Russia. Oxford: Berghahn Books.

Lucht, Hans. 2012. Darkness Before Daybreak. African Migrants Living on the Margins in Southern Italy Today. Berkeley: University of California Press.

Mains, Daniel. 2007. 'Neoliberal Times: Progress, Boredom, and Shame among Young Men in Urban Ethiopia'. American Ethnologist 34(4): 659-673.

Marcel, Gabriel. 1967. 'Desire and Hope'. In Readings in Existential Phenomenology, edited by Nathaniel Lawrence and Daniel O'Connor, 277-285. Englewood Cliffs, NJ: Prentice-Hall Inc.

Marcus, George. 2013. 'Afterword. Ethnography between the Virtue of Patience and the Anxiety of Belatedness Once Coevalness is Embraced'. Social Analysis 57(1): 143-155.

Mathur, Nayanika. 2014. 'The Reign of Terror of the Big Cat: Bureaucracy and the Mediation of Social Times in the Indian Himalaya'. Journal of the Royal Anthropological Institute 20(S1): 148-165.

Mauss, Marcel. 2000 [1925]. The Gift: The Form and Reason for Exchange in Archaic Societies. London, New York: Routledge.

Meyer, Birgit. 1998. "Make a Complete Break with the Past”. Memory and PostColonial Modernity in Ghanaian Pentecostalist Discourse'. Journal of Religion in Africa 28(3): 316-349. 
Miller, Daniel. 1994. Modernity: An Ethnographic Approach. Dualism and Mass Consumption in Trinidad. Oxford: Berg.

Minnegal, Monica. 2009. 'The Time is Right: Waiting, Reciprocity and Sociality'. In Waiting, edited by Ghassan Hage, 89-96. Melbourne: Melbourne University Press.

Miyazaki, Hirokazu. 2004. The Method of Hope. Anthropology, Philosophy, and Fijian Knowledge. Stanford, CA: Stanford University Press.

Miyazaki, Hirokazu. 2006. 'Economy of Dreams: Hope in Global Capitalism and Its Critiques'. Cultural Anthropology 21(2): 147-172.

Miyazaki, Hirokazu. 2010. 'The Temporality of No Hope'. In Ethnographies of Liberalism, edited by Carol J. Greenhouse. Philadelphia: University of Pennsylvania Press.

Munn, Nancy. 1992. 'The Cultural Anthropology of Time. A Critical Essay'. Annual Review of Anthropology 21: 93-123.

Navaro-Yashin, Yael. 2007. 'Make-Believe Papers, Legal Forms, and Counterfeit: Affective Interactions Between Documents and People in Britain and Cyprus' Anthropological Theory 7(1): 79-96.

Pelkmans, Matthijs (ed.). 2013. Ethnographies of Doubt. Faith and Uncertainty in Contemporary Societies. London: I.B. Tauris.

Povinelli, Elizabeth. 2011. Economies of Abandonment: Social Belonging and Endurance in Late Liberalism. Durham, NC: Duke University Press.

Povinelli, Elizabeth. 2012. 'The Will to be Otherwise/The Effort of Endurance'. South Atlantic Quarterly 111(3): 453-475.

Power, Michael. 1997. The Audit Society: Rituals of Verification. Oxford: Oxford University Press.

Procupez, Valeria. 2015. 'The Need for Patience: The Politics of Housing Emergency in Buenos Aires'. Current Anthropology 56, (S11): S55-S65.

Rabinow, Paul. 2008. Marking Time. On the Anthropology of the Contemporary. Princeton, NJ: Princeton University Press.

Rabinow, Paul and George E. Marcus with James D. Faubion and Tobias Rees. 2008. Designs for an Anthropology of the Contemporary. Durham, NC: Duke University Press.

Reed, Adam. 2011. 'Hope on Remand'. Journal of the Royal Anthropological Institute 17(3): 527-544.

Reeves, Madeleine. 2011. 'Staying Put? Towards a Relational Politics of Mobility at a Time of Migration'. Central Asian Survey 30(3-4): 555-576.

Robbins, Joel. 2001. 'Secrecy and the Sense of an Ending: Narrative, Time, and Everyday Millenarianism in Papua New Guinea and in Christian Fundamentalism. Comparative Studies in Society and History 43(3): 525-551.

Robbins, Joel. 2004. Becoming Sinners: Christianity + Moral Torment in a Papua New Guinea Society. Berkeley: University of California Press.

Robbins, Joel. 2007. 'Continuity Thinking and the Problem of Christian Culture'. Current Anthropology 48(1): 5-38.

Robbins, Joel. 2010. 'Anthropology, Pentecostalism, and the New Paul: Conversion, Event, and Social Transformation'. In Matthew Engelke and Joel Robbins (eds.), 
Global Christianity, Global Critique, Special Issue of The South Atlantic Quarterly 109(4): 633-652.

Robbins, Joel. 2011. 'On Messianic Promise'. In Echoes of the Tambaran: Masculinity, History and the Subject in the Work of Donald F. Tuzin, edited by David M. Lipset and Paul Roscoe, 183-194. Canberra: Australian National University Press.

Robbins, Joel. 2013. 'Beyond the Suffering Subject. Toward an Anthropology of the Good'. Journal of the Royal Anthropological Institute 19: 447-462.

Robertson, Roland. 1992. Globalization. Social Theory and Global Culture. London: SAGE Publications.

Roitman, Janet. 2014. Anti-Crisis. Durham, NC: Duke University Press.

Rosa, Hartmut. 2013. Social Acceleration: A New Theory of Modernity. New York: Columbia University Press.

Rotter, Rebecca. 2016. 'Waiting in the Asylum Determination Process: Just an Empty Interlude?' Time \& Society 25(1): 80-101.

Ruddick, Susan. 2003. 'The Politics of Aging: Globalization and the Restructuring of Youth and Childhood'. Antipode 35: 335-364.

Sanjek, Roger (ed.). 1990. Fieldnotes. The Makings of Anthropology. Ithaca, NY: Cornell University Press.

Schuster, Liza. 2011. 'Dublin II and Eurodac: Examining the (Un)Intended(?) Consequences'. Gender, Place and Culture 18(3): 401-416.

Sennett, Richard. 2003. Respect in a World of Inequality. New York: W.W. Norton and Company.

Serres, Michel and Bruno Latour. 1995 [1990]. Conversations on Science, Culture, and Time. Ann Arbor: University of Michigan Press.

Schielke, Samuli. 2008. 'Boredom and Despair in Contemporary Egypt. Contemporary Islam 2(3): 251-270.

Schweizer, Harold. 2005. 'On Waiting.' University of Toronto Quarterly 74(3): 777-792. Schweizer, Harold. 2008. On Waiting. London: Routledge.

Scott, David. 2014. Omens of Adversity: Tragedy, Time, Memory, Justice. Durham, NC: Duke University Press.

Sjørslev, Inger. 2013. 'Boredom, Rhythm, and the Temporality of Ritual. Recurring Fieldwork in the Brazilian Candomblé. Social Analysis 57(1): 95-109.

Stepputat, Finn. 1992. 'Beyond Relief? Life in a Guatemalan Refugee Settlement in Mexico’. Ph.D. Dissertation, Institute of Cultural Sociology, University of Copenhagen.

Strathern, Marilyn. 1999. Property, Substance and Effect: Anthropological Essays on Persons and Things. London: Athlone Press.

Strathern, Marilyn. 2000. Audit Cultures. Anthropological Studies in Accountability, Ethics and the Academy. London: Routledge.

Sutton, Rebecca, Darshan Vigneswaran and Harry Wels. 2011. 'Waiting in Liminal Space: Migrants' Queuing for Home affairs in South Africa'. Anthropology Southern Africa 34(1\&2): 30-37. 
Taubes, Jacob. 2004. The Political Theology of Paul. Stanford, CA: Stanford University Press. Taussig, Michael. 2006. Walter Benjamin's Grave. Chicago: University of Chicago Press. Thomassen, Bjørn. 2014. Liminality and the Modern: Living through the In-between. London: Routledge.

Thompson, Edward P. 1967. 'Time, Work-Discipline, and Industrial Capitalism'. Past and Present 38 (December): 56-97.

Tomlinson, John. 2008. 'Global Immediacy'. In Cultural Politics in a Global Age, edited by David Held and Henriette Moore, 80-87. Oxford: Oneworld Publications.

Tomlinson, Matt. 2014. 'Bringing Kierkegaard into Anthropology. Repetition, absurdity, and curses in Fiji. American Ethnologist 41(1): 163-175.

Turner, Simon. 2012. Politics of Innocence. Hutu Identity, Conflict and Camp Life. Oxford: Berghahn Books.

Turner, Victor. 1969. The Ritual Process: Structure and Anti-Structure. Chicago: Aldine Publishing Co.

Vigh, Henrik. 2009. 'Wayward Migration: On Imagined Futures and Technological Voids'. Ethnos 74(1): 91-109.

Virilio, Paul. 1977. Speed and Politics: An Essay on Dromology. New York: Semiotext(e).

Vostal, Filip. 2015. 'Academic Life in the Fast Lane: The Experience of Time and Speed in British Academia. Time and Society 24(1): 71-95.

Weber, Max. 2013 [1922]. Economy and Society. Berkeley: University of California Press.

Whyte, Michael 2013. 'Episodic Fieldwork, Updating, and Sociability'. Social Analysis 57(1): 110-121.

Whyte, Zachary. 2011. 'Enter the Myopticon: Uncertain Surveillance in the Danish Asylum System'. Anthropology Today 27(3): 18-21.

Willis, Paul. 1977. Learning to Labour: How Working Class Kids Get Working Class Jobs. Farnborough: Saxon House.

Willis, Paul. 2003. 'Twenty Five Years On: Old Books, New Times'. In Learning to Labour in New Times, edited by Nadine Dolby and Greg Dimitriadis, with Paul Willis, 144-168. London: Routledge.

Wolf, Eric. 1982. Europe and the People Without History. Berkeley and Los Angeles: University of California Press.

Ylijoki, Oili-Helena and Hans Mäntylä. 2003. 'Conflicting Time Perspectives in Academic Work'. Time and Society 12(1): 55-78. 